\title{
Spleen cells of non-obese diabetic mice fed with pig splenocytes display modified proliferation and reduced aggressiveness in vitro against pig islet cells
}

\author{
S. You, E. Gouin, P. Saï \\ Cellular and Molecular Immuno-Endocrinology, University/INRA/ENVN, Nantes, France
}

Summary A new means of modifying xenogeneic reaction to pig islet cells, which involves pre-feeding with pig spleen cells, was investigated for the first time in the non-obese diabetic (NOD) mouse. Compared with controls, mice fed with pig spleen cells displayed much higher splenocyte proliferation in response to pig spleen and islet cells $(p<0.0001)$. This enhanced proliferation was specific for the species providing the fed cells. Positive relationships $(p<$ 0.01 ) were found between increased splenocyte proliferation in response to pig spleen or islet cells and the number of cells per feeding or the number of daily feedings. Concomitantly, while co-incubation with splenocytes from control mice led to inhibition of both basal and stimulated insulin releases from pig islet cells $(p<0.001)$, this aggressiveness was abolished $(p<0.001)$ after co-culture with splenocytes from mice fed with pig spleen cells. The proliferative responses of splenocytes from fed or control mice to pig islet or spleen cells were abolished after removal of plastic-adherent cells, indicating that the major indirect pathway of T-cell activation was unchanged by pig spleen cell feeding. The main T-splenocyte subsets involved were restricted to MHC class II as they did not proliferate in the presence of monoclonal antibodies (mAbs) directed at I-A molecules. In mice fed with pig spleen cells, as well as in control mice, the blocking of CD4 + T cells with mAbs led to abolition of proliferation $(p<0.002)$, while the blocking of CD8 + led to a less marked effect. However, an increase in the blocking effect of anti-CD8 mAbs was noted in mice fed with pig spleen cells $(p<0.02)$. In control mice, the main splenocyte subset involved during proliferation in response to pig islet cells was Th1, since interferon $\gamma$ (IFN $\gamma$ ) production increased significantly $(p<0.01)$ while that of interleukin-10 (IL-10) increased only slightly. The main change observed in mice fed with pig spleen cells was a marked increase in basal IL-10 production $(p<0.01)$ and the basal IL-10/IFN $\gamma$ ratio $(p<0.001)$. It seems likely that feeding with pig spleen cells shifted the Th1/Th2 balance towards a dominance of Th2-type class II-restricted CD4 + T cells, which may have been conducive to activating CD8 + suppressor $T$ cells. In any event, oral administration of pig cells modified xenogeneic cellular response, which may have implications for xenografts of pig islets. In a more general sense, physiological feeding of cells from xenogeneic species would appear to have certain effects on the immune system. [Diabetologia (1998) 41: 955-962]

Keywords Islets, pig, insulin release, xenograft, oral tolerance, feeding.
Received: 17 November 1997 and in revised form: 25 February 1998

Corresponding author: P Saï, Immuno-Endocrinology, ENVN, Atlanpole, La Chantrerie, BP 40706, 44307 Nantes cedex 03, France

Abbreviations: NOD, Non-obese diabetic mouse; SPF, specific pathogen-free pigs; mUW, modified University of Wisconsin solution; PBS, phosphate buffered saline; SI stimulation index; GALT, gut associated lymphoid tissue; Ts cells, class I restricted CD8 + suppressor cells; Il, interleukin; INF $\gamma$, interferon $\gamma$.
Human Type I (insulin-dependent) diabetes mellitus could be treated by a pig islet graft. Even though advances in the understanding of hyperacute rejection of such a discordant xenograft have been made, cellmediated rejection cannot be disregarded [1-3], specifically in the case of islets which may be less susceptible to hyperacute rejection $[4,5]$. The nature of cellular immune xenoreaction to adult pig islets is still not completely known. Our previous study of the intensity and mechanisms of mouse cell-mediated reac- 
tion to pig islets revealed higher lymphocyte proliferation against pig islets in non-obese diabetic (NOD) mice than in other mouse strains [6] and led us to conduct the present study in the NOD mouse, which represents the best model for human Type I diabetes [7].

Many strategies may be considered in an effort to counteract the cellular rejection of pig islet xenografts [8]. This report describes a novel approach not previously investigated, consisting of modifying reaction against pig islets by feeding animals xenogeneic pig cells. We compared the proliferation of splenocytes from NOD mice fed or not with pig spleen cells and investigated the effect of such feeding on their aggressiveness in vitro on pig islets through analysis in perifusion of islet cells incubated with murine splenocytes.

Oral administration of antigens elicits local mucosal responses but also has a propensity to down-regulate systemic response to antigens [9]. Although the mechanisms involved in such oral tolerance are incompletely understood, this approach has been used to suppress immune response in autoimmune diseases [10-13], including Type I diabetes [14-18], and has also proved effective in down-regulating the response against alloantigens [19-21]. In the field of pancreatic grafts, it has been suggested that feeding pigs with allogeneic pancreatic extracts could slow down rejection [22]. The present study is the first to address the effects of orally administered pig cells on xenogeneic response to isolated islets in a discordant situation.

\section{Materials and methods}

Specific pathogen-free (SPF) pigs. Islet and splenocyte isolations. Islets were isolated from pigs raised in SPF conditions which offer protection against the risk of transmitting infectious agents [23-25]. We have shown that this strategy minimises microbial contamination [26, 27]. Pancreata were removed from Large White SPF pigs (80-120 kg) aged 20-30 weeks [28] in an operating room with a protected environment, they were soaked in betadine solution, immediately inflated with $100 \mathrm{ml}$ ice-cold sterile modified University of Wisconsin (mUW) solution and transported in a sterile receptacle containing mUW. Pancreata were then inflated again with $0.5 \mathrm{ml} / \mathrm{g}$ of mUW solution containing $2 \mathrm{mg} / \mathrm{ml}$ collagenase $\mathrm{P}$ (Boehringer Mannheim, Meylan, France) and placed in a digestion chamber filled with mUW solution kept at $36^{\circ} \mathrm{C}$. The flow rate through the chamber was $40 \mathrm{ml} / \mathrm{min}$. Crude islets were pelleted by centrifugation, suspended in mUW and purified on continuous Optiprep gradient (Life International Technology, Cergy-Pontoise, France) with a COBE 2991 processor [29]. Islet purity, as assessed by dithizone staining, exceeded $90 \%$. Insulin release from SPF pig islets in response to different stimuli was highly reproducible [27]. Islets were then treated with EDTA and dispase to obtain islet cell suspensions before the cells were enumerated and suspended in Ham's F10 medium (5.5 mmol/1 glucose) (Biomédia, Boussens, France) supplemented with $2 \%$ Ultroser (BioSepra SA, Villeneuve la Garenne, France), antibiotics (penicillin, streptomycin) (Seromed, Berlin, Germany) and fungizone at $37^{\circ} \mathrm{C}$ in a
$\mathrm{CO}_{2}$ incubator. Islet cells were cultured for 1 week before being used in the experiments. Pig spleens were removed, and splenocytes were prepared as described for mouse splenocytes.

NOD mice and splenocyte preparations. Feeding of mice with pig splenocytes. NOD mice (Clea, Tokyo, Japan), have been bred in our laboratory since 1986 . The incidence of diabetes in our colony is $65 \%$ in females and $5 \%$ in males by 300 days of age. Three-month-old non-diabetic female NOD mice were used for all experiments in this study. Spleens were removed in Hank's balanced salt solution (HBSS) (Seromed). Splenocytes were flushed out and erythrocytes were lysed by ammonium chloride. The cell suspension was resuspended in RPMI containing $1.5 \%$ autologous decomplemented mouse serum.

Pig splenocytes, prepared as lysates by a single freezing and thawing cycle and suspended in phosphate-buffered saline (PBS), were administered orally in a volume of $0.3 \mathrm{ml}$ per mouse per feeding. Daily oral administrations of varying numbers of pig spleen cells $\left(1,5\right.$, or $\left.25 \times 10^{6}\right)$ were performed for varying periods $(2,5,11$, or 20 days) before in vitro responses of mouse splenocytes to pig islet or spleen cells were tested 12 days after the last gavage. In some experiments, NOD mice were also fed with syngeneic spleen cells. The control groups of NOD mice received daily gastric intubations of PBS.

Proliferation of mouse splenocytes in response to pig islet cells or splenocytes. Spleen cells from mice fed or not with pig spleen cells were aliquoted into flat-bottomed 96-well microtitre plates (Costar, Cambridge, Mass., USA) at 10\% $/$ well with 60000 pig islet cells or splenocytes in $0.3 \mathrm{ml}$ culture medium containing $1.5 \%$ autologous decomplemented mouse serum. In some experiments, 60000 syngeneic mouse spleen cells or human-mouse heteromyeloma cells SPM4-O (Hoffmann-La Roche, Basel, Switzerland) were seeded into each well as stimulator cells for mouse splenocytes. Plates were incubated for 4 days and pulsed by adding $0.5 \mu \mathrm{Ci}\left[{ }^{3} \mathrm{H}\right]$ thymidine (specific activity $20 \mathrm{Ci} / \mathrm{mmol}$; Amersham, Les Ulis, France) for the final $18 \mathrm{~h}$. Cells were then harvested and counted. Data were obtained from the mean values of quadruplicate wells, and the results were also expressed by a stimulation index (SI), i.e. the ratio between the mean count with stimulator islet cells and the mean basal count. The interassay coefficient of variation $(\mathrm{SD} /$ mean $\times 100)$ of the SI ranged from 5 to $8 \%$.

Similar assays in response to pig islet cells were performed while mouse T-splenocyte subsets were blocked for the whole incubation period with $10 \mu \mathrm{g} / \mathrm{ml}$ monoclonal antibodies (mAbs). Rat IgG mAbs directed against mouse CD4 or CD8 (Clinisciences, Montrouge, France) were used. Major histocompatibility complex (MHC) restriction was tested in the presence of $\operatorname{IgG} 2$ a mAbs directed at NOD class II molecules $\mathrm{I}^{-\mathrm{A}^{\mathrm{g} 7}}$ (10-3-6) or which did not cross-react with NOD class II molecules (anti-I-A $\left.{ }^{\mathrm{d}}, \mathrm{MKD} 6\right)$. Antibodies of similar isotypes (IgG2 b and IgG2 a, respectively) were used as controls. To determine whether mouse $\mathrm{T}$ splenocytes interact directly or indirectly with pig islet cells, mouse T splenocytes were enriched by removal of adherent cells by two successive incubations on plastic Petri dishes (Nunc, Rostkilde, Denmark) for $3 \mathrm{~h}$ at $37^{\circ} \mathrm{C}$, before being introduced into the proliferation assay.

Th1/Th2 cytokine secretion. Under similar conditions to those described above for proliferation, $100 \mu \mathrm{l}$ of supernatant was removed from each well after 2 days of co-incubation for interferon- $\gamma$ (INF $\gamma$ ) and interleukin-10 (IL-10) assays. Murine INF $\gamma$ and IL-10 concentrations were determined by ELISA (Biotrak ELISA system, Amersham Life Science) using a solid phase involving a capture antibody bound to the wells of a microtitre plate and a horseradish peroxidase-conjugated anti- 

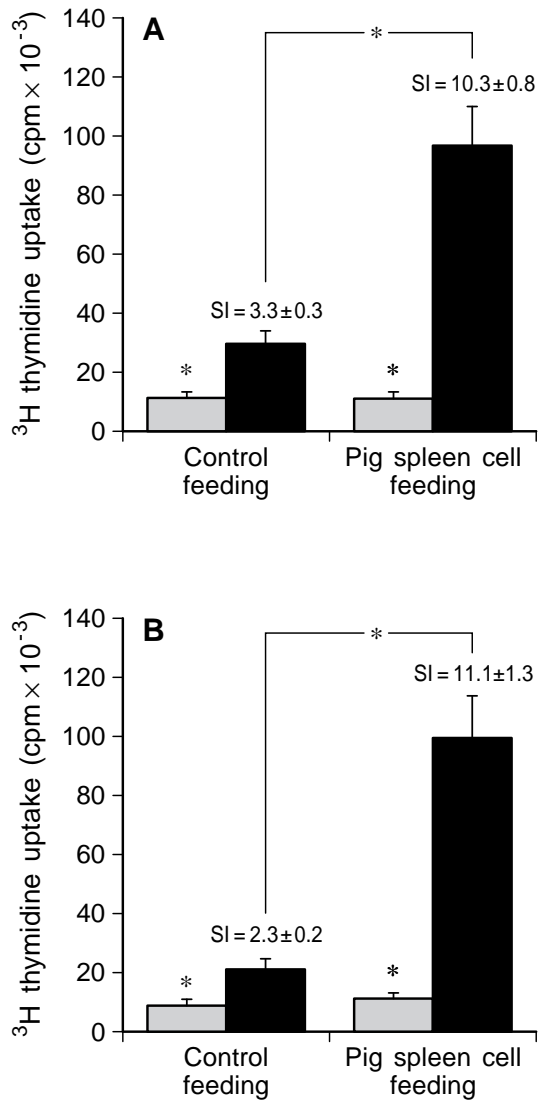

Fig. 1. Splenocyte responsiveness of NOD mice fed PBS (control feeding, $n=25)$ or pig spleen cells $(n=25)$ to stimulator islet cells (PIC) (A) or splenocytes (B) from SPF pigs. Daily administration of $25 \times 10^{6}$ pig spleen cells was given for 11 days. The NOD mice were then analysed 12 days after withdrawal of oral treatment. Results indicate the mean \pm SEM of ${ }^{3} \mathrm{H}$-thymidine uptake by $10^{6}$ splenocytes alone (1i) or co-incubated for 4 days with 60000 PIC $(\square)$. $*(p<0.0001)$ indicates significant differences between basal and PIC-stimulated proliferations in mice fed with pig spleen cells or PBS, and in stimulation indices (SI) between mice fed with pig spleen cells or PBS

body for detection. Standard curves were generated in each assay using recombinant mouse interleukins.

Aggressiveness of mouse splenocytes against pig islet cells. Pig islet cells $\left(6.5 \times 10^{5}\right)$ were co-cultured with splenocytes $\left(25 \times 10^{6}\right)$ from NOD mice, fed or not with pig spleen cells, in flat-bottomed 24-well microtitre plates (Costar, Cambridge, Mass., USA) incubated at $37^{\circ} \mathrm{C}$ in $5 \% \mathrm{CO}_{2}$ in a final volume of $1.5 \mathrm{ml}$ for 4 days. Pig islet-mouse splenocyte cultures were then placed in a perifusion chamber (Swinnex 13; Millipore Corp, Bedford, Mass., USA) supplied with Krebs Ringer bicarbonate buffer (KRBB) containing $0.5 \%$ bovine serum albumin, $5 \mathrm{mmol} / \mathrm{l}$ each of pyruvate, fumarate and glutamate (Sigma, St Quentin Fallavier, France), and $2.8 \mathrm{mmol} / \mathrm{l}$ glucose. The flow rate was $1 \mathrm{ml} / \mathrm{min}$. Chambers and perifusion media were kept at $37^{\circ} \mathrm{C}$ in a water bath, and the perfusates were gased with a $95 \% \mathrm{O}_{2}-5 \% \mathrm{CO}_{2}$ mixture. Islet cells were first perifused for $30 \mathrm{~min}$ in $2.8 \mathrm{mmol} / \mathrm{l}$ glucose, then for $20 \mathrm{~min}$ in $18 \mathrm{mmol} / \mathrm{l}$ glucose and $10 \mathrm{mmol} / \mathrm{l}$ theophylline, and finally in $2.8 \mathrm{mmol} / \mathrm{l}$ glucose. Effluents were collected for insulin radioimmunoassay (CIS Bio International, Gif-sur-Yvette, France) using porcine insulin as standard. Stimulated insulin release

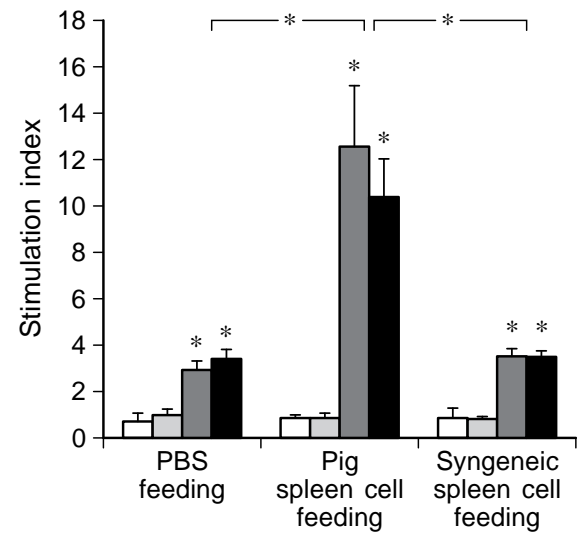

Fig. 2. Specificity of enhanced proliferation observed in mice fed with pig spleen cells. NOD mice $(n=10$ in each group) were fed for 11 days with PBS, pig spleen cells, or syngeneic NOD splenocytes. Daily oral administration of $25 \times 10^{6}$ cells was given for 11 days. The mice were analysed 12 days after withdrawal of oral treatment. Proliferative responses of $10^{6}$ NOD splenocytes were measured after culture with 60000 pig

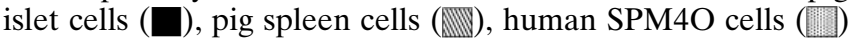
or syngeneic NOD splenocytes $(\square)$ for 4 days. Results indicate mean \pm SEM of the stimulation index (SI), calculated as the ratio of the mean count with stimulator cells to the mean basal count. * Significant increase compared with splenocytes alone, or between different groups of mice $(p<0.01)$

was calculated as the area under the curve during the stimulation period. SIs were calculated by dividing insulin secretion during the stimulation period by insulin secretion under basal conditions.

Stastistical analysis. Data are presented as mean values \pm SEM. The statistical significance of differences was evaluated using Student's $t$-test. Regression analyses were used to characterize the relationships between in vitro mouse splenocyte proliferation in response to pig cells and the number of cells per feeding or the number of daily feedings. $P$ less than 0.05 was considered as significant.

\section{Results}

Effect of feeding pig spleen cells on xenorecognition of pig cells by mouse splenocytes in vitro. Splenocytes from control NOD mice fed PBS $(n=25)$ recognised pig islet cells and spleen cells (Fig.1A and B) since reproducible proliferations (SI: $3.3 \pm 0.3$ and $2.3 \pm 0.2$, respectively) were detected $(p<0.0001)$. It is noteworthy (Fig.1B) that mice fed with pig spleen cells in a "standard" regimen $\left(25 \times 10^{6}\right.$ cells per daily feeding for 11 days, $n=25)$ displayed much greater $(p<$ $0.0001)$ splenocyte proliferation in response to pig spleen cells (SI: $11.1 \pm 1.3$ ) than did control mice. Mice fed with pig spleen cells also displayed markedly enhanced $(p<0.0001)$ splenocyte proliferation in response to pig islet cells (SI: $10.3 \pm 0.8$, Fig.1A). Feeding with pig spleen cells did not increase response to human or mouse stimulator cells (Fig.2). 

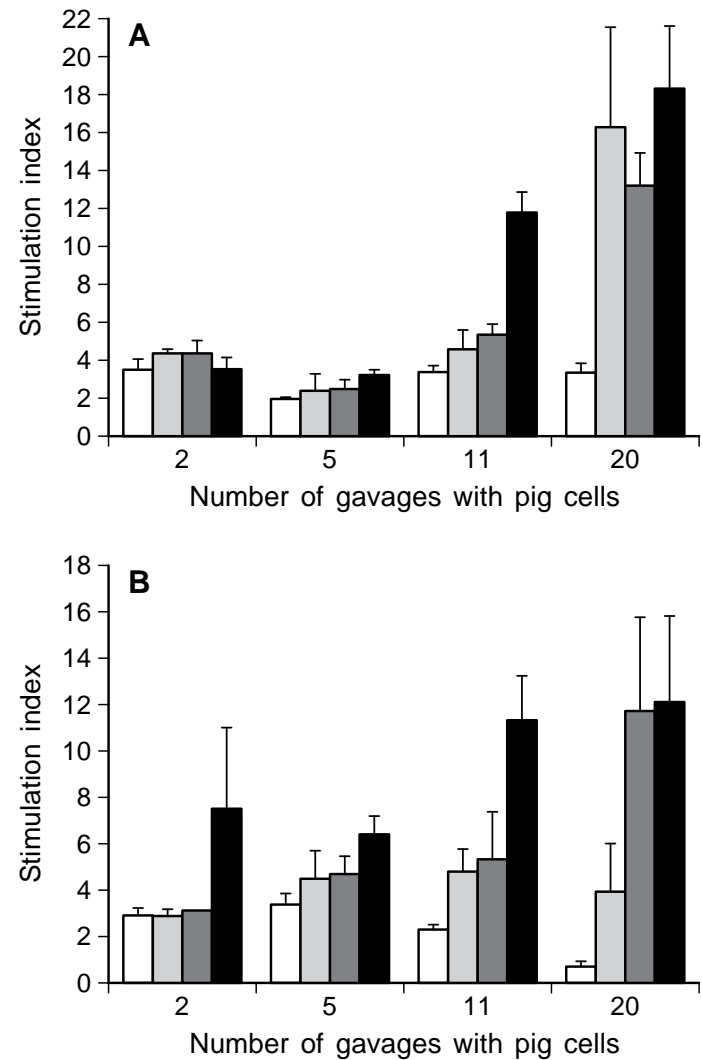

Fig.3. Influence of the number of cells per feeding and the number of feedings in enhanced proliferation observed in NOD mice fed pig spleen cells. Daily gavages with varying numbers of pig spleen cells $\left(1,5\right.$, or $25 \times 10^{6}$; $\square$, $\mathbb{M}$, and $\square$, respectively) were performed for varying periods $(2,5,11$, or 20 days). The proliferation of $10^{6}$ mouse splenocytes in response to 60000 pig islet (A) or spleen (B) cells was tested 12 days after the last feeding. The responses of splenocytes from mice fed PBS are also represented $(\square)$. Results are expressed as the mean of the stimulation index (SI) \pm SEM of 8 mice in each group. Relationships were found between increased splenocyte proliferation in response to either pig islet or spleen cells and the number of cells per feeding $(r=0.520$ and 0.718 , respectively, $p<0.01$ for both) or the number of feedings ( $r=0.580$ and 0.543 , respectively, $p<0.01$ for both)

Conversely, feeding syngeneic spleen cells $(n=10)$ did not modify proliferation in response to pig islet or spleen cells. Feeding with pig spleen cells, as compared with PBS or syngeneic spleen cells $(n=8$ in each group), did not modify proliferation in response to concanavalin A (SI: $21.7 \pm 4.4,20.3 \pm 7.7$, and $21.2 \pm 4.8$, respectively), phytohaemagglutinin (PHA) (SI: $8.6 \pm 2.9,7.9 \pm 2.8$, and $8.0 \pm 2.6$, respectively), lipopolysaccharide (LPS) (SI: $8.7 \pm 1.9,8.4 \pm$ 1.8 , and $7.8 \pm 1.6$, respectively), or anti-CD3 $\mathrm{mAbs}$ (SI: $11.9 \pm 1.9,10.8 \pm 2.0$, and $11.3 \pm 1.8$, respectively).

Positive relationships were found between increased splenocyte proliferation in response to either pig islet (Fig. 3A) or spleen (Fig. 3B) cells and the number of cells per feeding ( $n=8$ in each subgroup, $r=0.520$ and 0.718 , respectively, $p<0.01$ for both) or the number of daily feedings $(n=8$ in each sub-

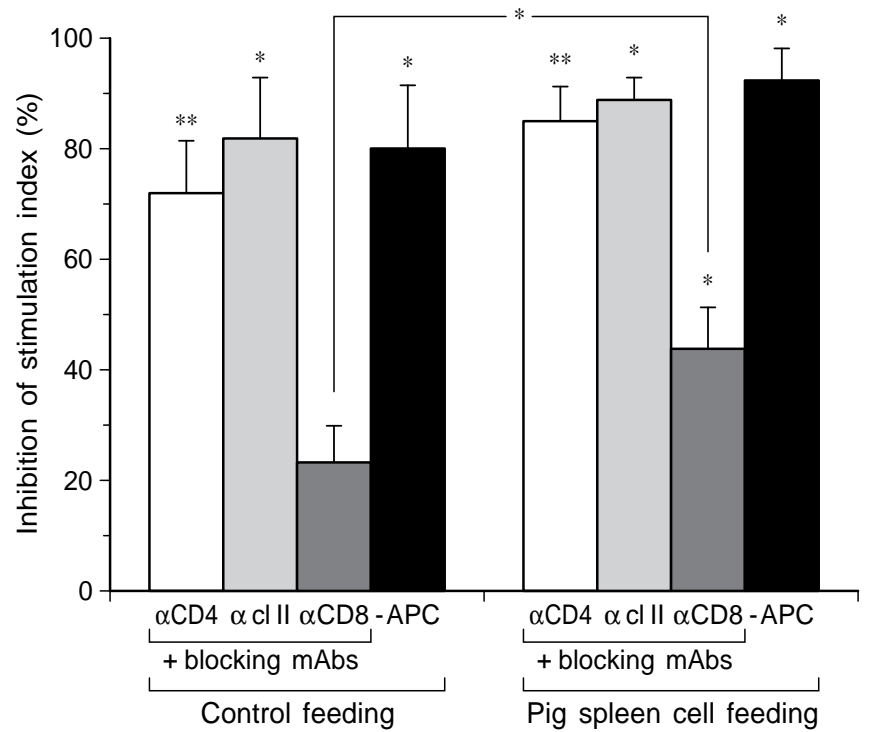

Fig. 4. Splenocyte subsets and the pathway involved in proliferation of splenocytes from NOD mice fed pig spleen cells. Daily administration of $25 \times 10^{6}$ pig spleen cells was given for 11 days. The mice were analysed 12 days after withdrawal of oral treatment. Splenocytes $\left(10^{6}\right)$ from mice fed with PBS (contol feeding) or pig spleen cells were cultured with 60000 pig islet cells (PIC). Proliferation was tested in the presence

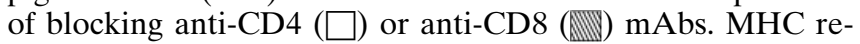
striction was tested in the presence of blocking mAbs directed at class II I-A molecules (啰). Proliferation after removal of plastic-adherent antigen-presenting cells (APC) are also represented $(\square)$. Results are expressed as the mean percentage of inhibition \pm SEM of the stimulation index (SI) for 15 mice in each group. Control co-incubations in the absence of mAbs and plastic-adherence represent the $100 \%$ values of SI $(5.5 \pm$ 0.9 for mice fed PBS and 20.2 \pm 3.6 for mice fed pig spleen cells, respectively). Control mAbs of similar isotypes were without blocking effects. ${ }^{*} p<0.02, * * p<0.002$

group, $r=0.580$ and 0.543 , respectively, $p<0.01$ for both). Proliferation increased up to the highest number of cells per feeding $\left(25 \times 10^{6}\right)$ and the highest number of feedings $(\times 20)$ tested.

After removal of plastic-adherent cells, the proliferative responses of splenocytes from mice fed PBS or pig spleen cells were abolished $(n=15$ in each group; $p<0.02$ ) in response to pig islet or spleen cells (Fig.4), indicating that the major pathway of T-cell activation was indirect and unchanged by oral administration of pig spleen cells. The main T-splenocyte subsets involved were restricted to mouse MHC class II as they did not proliferate $(p<0.02)$ in the presence of mAbs directed at I-A molecules (Fig. 4). In mice fed pig spleen cells, as well as in control mice $(n=15$ in each group), the proliferation of splenocytes in response to pig islet cells involved mainly CD4 T cells since the SI was significantly decreased $(p<0.002)$ when CD $4+$ cells were blocked with mAbs, while the blocking of $\mathrm{CD} 8+$ cells produced less effect (Fig. 4). However, a significant increase in the blocking effect of anti-CD8 mAbs was noted in 

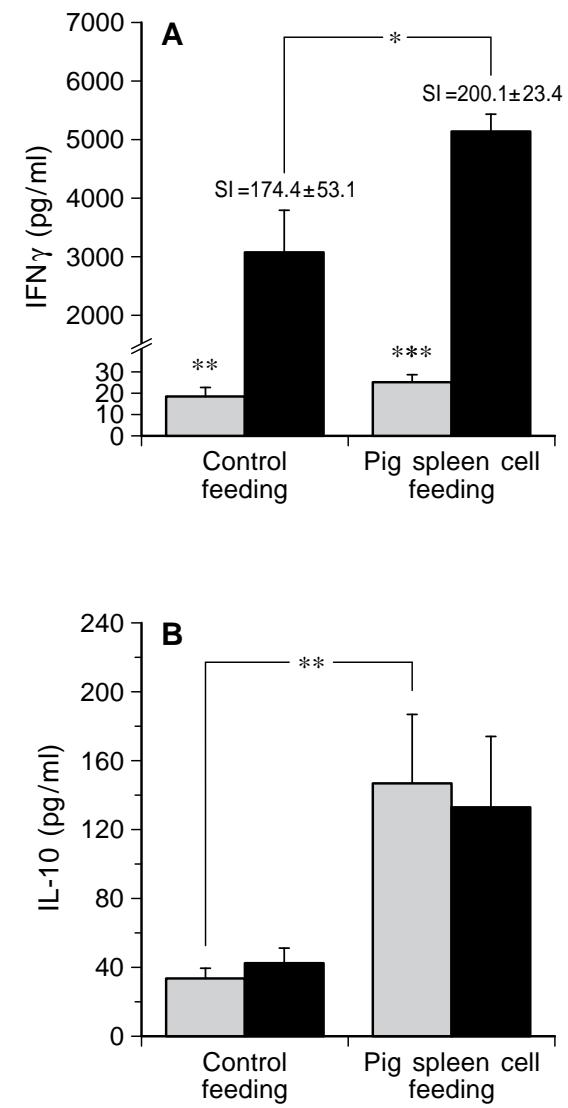

Fig.5. In vitro production of cytokines by splenocytes from NOD mice previously fed pig spleen cells. Daily administrations of PBS (control feeding) or $25 \times 10^{6}$ pig spleen cells were performed for 11 days. Twelve days after withdrawal of oral treatment, mouse splenocytes $\left(10^{6}\right)$ were cultured with 60000 pig islet cells (PIC) for $48 \mathrm{~h}$. Columns represent the mean production of IFN- $\gamma(\mathbf{A})$ and IL-10 (B) from five experiments in the absence of stimulator cells (四) or in response to challenge with PIC (ם). * $p<0.05$, ** $p<0.01$, and *** $p<0.001$

mice fed pig spleen cells as compared with those fed PBS $(p<0.02)$. In all cases, control mAbs of similar isotypes were without blocking effects.

In control mice $(n=5)$, the main splenocyte subset involved during proliferation in response to pig islet cells was Th1, since IFN $\gamma$ production increased significantly (159-fold, $p<0.01)$ as compared with basal production (Fig.5). Involvement of Th2 cells appeared much lower since IL-10 production increased only 1.3 -fold. The main modification in mice fed with pig spleen cells $(n=5$, Fig. 5$)$ was a markedly increased basal IL-10 production in the absence of stimulatory islet cells $(p<0.01)$. As basal IFN $\gamma$ was not significantly increased, the basal IL-10/IFN $\gamma$ ratio was thus increased $(p<0.001)$ by feeding with pig spleen cells. As the basal level of IL-10 was already very high, no additional increase was observed in mice fed with pig spleen cells during in vitro challenge with pig islet cells. A slight increase of IFN $\gamma$ following pig islet cell challenge could be observed in mice fed pig spleen cells $(p<0.05)$.

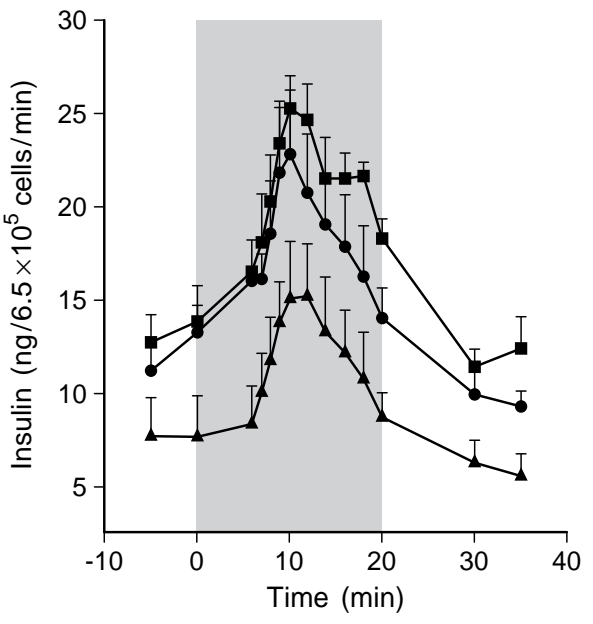

Fig. 6. Reduced alteration of insulin release from pig islet cells induced by mouse splenocytes in vitro in NOD mice fed with pig spleen cells. Insulin secretory response of 650000 pig islet cells (PIC) cultured alone $(\square, n=5)$ or with $25 \times 10^{6}$ splenocytes from mice fed PBS $(\boldsymbol{\Lambda}, n=7)$ or pig spleen cells $(\boldsymbol{O}$, $n=7$ ). Daily oral administrations of $25 \times 10^{6}$ pig spleen cells were performed for 11 days. The mice were analysed 12 days after withdrawal of oral treatment. Perifusions of islet cells were performed after 4-day co-incubation with mouse splenocytes. The glucose-theophylline stimulation period is indicated by the grey area. Each point indicates the mean value \pm SEM

Reduced alteration of insulin release from pig islet cells by mouse splenocytes in vitro in NOD mice fed pig spleen cells. Co-incubation with splenocytes from control NOD mice fed PBS led to inhibition of both basal and stimulated insulin releases $(p<0.001$ for both) as compared with pig islet cells cultured alone (Fig. 6). Contrary to results for co-incubation with splenocytes from seven control mice, inhibition of both basal and stimulated insulin releases from pig islet cells was almost completely abolished $(p<0.001)$ after co-culture with splenocytes from seven NOD mice previously given $25 \times 10^{6}$ pig spleen cells per daily feeding for 11 days (Fig. 6).

\section{Discussion}

This study is the first to describe the effects of prefeeding with xenogeneic pig spleen cells on mouse cellular immune response to pig cells. NOD mice pre-fed with pig spleen cells displayed highly increased proliferation of splenocytes in response to pig spleen cells. Moreover, this increased proliferation was as intense in response to pig islet cells. Conversely, feeding of pig spleen cells did not increase responses to human or mouse stimulator cells, and feeding with mouse spleen cells did not modify responses to pig islet cells or spleen cells. The enhanced proliferation from mice fed pig spleen cells was thus specific for the species producing the fed cells but not for the cell type, a phenomenon that could be of 
interest from a clinical point of view. It was not determined which pig antigen(s) of the fed spleen cells was(were) responsible for the observed effect. By analogy with the down-regulation of response to MHC antigens by orally administered allogeneic cells $[20,21,30]$, it may be speculated that molecules of the pig MHC shared by the fed cells could have been involved since they represent major targets for xenogeneic cellular recognition [31]. This hypothesis could be tested by feeding pig MHC antigens to the mice instead of whole cells.

The enhanced splenocyte proliferation in response to either pig spleen cells or islet cells was related both to the number of cells per feeding and the number of daily feedings, and increased up to the highest number of feedings and the highest number of cells per feeding tested. Thus, hyporesponsiveness was not detected with the high doses of orally administered antigens described in other systems $[32,33]$, although a higher number of fed pig spleen cells than that used in our experiments might induce such anergy.

As lymphocyte proliferation is not indicative of aggression against target cells, we also measured dynamic basal and stimulated insulin releases from pig islet cells co-incubated with mouse splenocytes. This test allows detection of a decrease in insulin release due to aggression of beta cells and provides a model for certain aspects of xenogeneic rejection. While splenocytes from control mice inhibited basal and stimulated insulin releases from pig islet cells, this inhibition was almost completely abolished during coincubation with splenocytes from mice pre-fed with pig spleen cells. This reduction of aggressiveness was apparent in both basal and stimulated insulin release, possibly indicating a decrease of both lysis or functional inhibition of islet cells. Further studies are needed to determine whether a relation exists between increased splenocyte proliferation and reduced pig islet aggression in mice fed pig cells.

Our study provides preliminary information on the mechanisms that may be induced in mice fed with pig spleen cells. Depending on several parameters, oral tolerance could occur and three mechanisms may be involved: T-cell anergy, clonal deletion, and active suppression [32-36]. As anergy and clonal deletion can be excluded in our experiments because of increased proliferation after feeding, induction of active suppression appears to be a likely mechanism. In experimental systems distinct from xenoreaction, antigen feeding gave rise to class I restricted CD8 + suppressor T (Ts) cells in gut-associated lymphoid tissue (GALT) and spleen [37, 38] with the support of class II restricted Th cells [39]. Antigen presenting cells from the intestinal lamina propria activate CD8 + T cells preferentially [40], and the lamina propria contains CD8 + T cells of naive phenotype [41], indicating that GALT could be committed to the gen- eration of Ts cells. In addition, CD $4+\mathrm{T}$ cells of GALT can also be activated following antigen feeding, which could be conducive to the activation of CD8 + Ts cells. In fact, antigen feeding modifies the Th1/Th2 ratio of CD4 + Th cells. Th2 cells secreting IL-4 and IL-10 [42, 43], as well as a regulatory subset secreting transforming growth factor- $\beta[10,36]$, are mainly induced, even though the production of Th1 cytokines, e.g. IFN- $\gamma$, has also been demonstrated [44]. Even though incomplete, our results suggest for the first time that the mechanisms induced by feeding xenogeneic cells may be consistent with the above conclusions drawn from other systems. The proliferative response of NOD splenocytes to pig cells involved an indirect T-cell activation pathway. In mice fed pig spleen cells, as well as in control mice, the blocking of MHC class II restricted CD $4+\mathrm{T}$ cells led to abolition of proliferation, while the blocking of CD8 + led to a less significant effect, indicating that CD4 cells could be conducive to activating CD8 cells. Moreover, a significant increase in the blocking effect of CD8 cells was noted in mice fed with pig spleen cells, a result which may correspond to induction of Ts cells, even though the assumption that these CD8 cells are assimilated to Ts cells still needs to be confirmed.

In control mice, the main T-splenocyte subset involved during proliferation in response to pig islet cells was Th1, since IFN $\gamma$ production markedly increased while IL-10 production only increased very slightly. Firstly, the main modification in mice fed with pig spleen cells was a marked increase in basal IL-10 production. Since basal IFN $\gamma$ was not modified, the basal IL-10/IFN $\gamma$ ratio was increased by feeding pig spleen cells, indicating the induction of Th2 cells. Secondly, as the basal level of IL-10 was already very high in mice fed with pig spleen cells, no additional increase was observed during in vitro challenge with pig cells. A slight increase of IFN $\gamma$ production following pig cell challenge was detected in mice fed pig spleen cells as compared to control mice, confirming that Th1 cell could also be induced after xenoantigen feeding [44]. Separations of T-cell subsets or cloning studies after pig cell feeding could ultimately help to indicate the cellular origin of these cytokine modifications and their possible relations with increased spleen cell proliferation and aggressiveness on pig islets. The present data suggest that feeding NOD mice with pig spleen cells could have shifted the Th1/Th2 balance towards a dominance of Th2 CD4 + T-cells, which may have been conducive to activating CD8 + Ts cells.

In conclusion, this study suggests that oral administration of pig cells constitutes a novel approach to modifying xenogeneic cellular response and decreasing aggressiveness against pig islet cells, even though this propensity to decrease aggressiveness needs to be tested in vivo by feeding mouse recipients of por- 
cine islets with pig cells. More generally, feeding of cells from xenogeneic species is not without consequences for the immune system.

Acknowledgements. We are grateful to Mrs. M. Ouary, Mr. C. Chevallier, Mrs. M. Allard, and Mrs. S. Pogu for their excellent collaboration. This work was supported by grants from the Pays de la Loire and Brittany regions through the assistance of the Pôle Agronomique Ouest.

\section{References}

1. Bach FH, Robson SC, Winkler H et al. (1995) Barriers to xenotransplantation. Nature Med 1: 869-873

2. Platt JL (1996) Xenotransplantation: recent progress and current perspectives. Curr Opin Immunol 8: 721-728

3. Parker W, Saadi S, Lin SS, Holzknecht ZE, Bustos M, Platt JL (1996) Transplantation of discordant xenografts: a challenge revisited. Immunol Today 8: 373-378

4. Mirenda V, Le Mauff B, Cassard A et al. (1997) Intact pig pancreatic islet function in the presence of human xenoreactive natural antibody binding and complement activation. Transplantation 63: 1452-1462

5. Schaapherder AFM, Wolvekamp MCJ, Te Bulte MJW, Bouwman E, Gooszen HG, Daha MR (1996) Porcine islet cells of Langerhans are destroyed by human complement and not by antibody-dependent cell-mediated mechanisms. Transplantation 62: 29-33

6. Rivereau AS, You S, Lalain S, Gouin E, Saï P (1998) In vitro xenorecognition of adult pig pancreatic islet cells by splenocytes from non-obese diabetic or non-diabetesprone mice. Transplantation (in press)

7. Castano L, Eisenbarth GS (1990) Type 1 diabetes: a chronic autoimmune disease of man, mouse and rat. Annu Rev Immunol 8: 647-679

8. Azimadeh A, Meyer C, Ravanat C, Cazenave JP, Wolf P (1996) Xenograft rejection: molecular mechanisms and therapeutic prospects. Hematology and Cell Therapy 38: 331-343

9. Friedman A, al Sabbagh A, Santos LM et al. (1994) Oral tolerance: a biologically relevant pathway to generate peripheral tolerance against external and self antigens. Chem Immunol 58: 259-290

10. Khoury S, Hancock WW, Weiner HL (1992) Oral tolerance to myelin basic protein and natural recovery from experimental autoimmune encephalomyelitis are associated with downregulation of inflammatory cytokines and differential upregulation of transforming growth factor $\beta$, interleukin4 , and prostaglandin E expression in the brain. J Exp Med 176: $1355-1364$

11. Trentham D, Dynesius-Trentham R, Orav E (1993) Effects of oral administration of collagen on rheumatoid arthritis. Science 261: 1727-1730

12. Weiner H, Mackin, Matsui M (1993) Double blind pilot trial of oral tolerization with myelin antigens in multiple sclerosis. Science 259: 1321-1324

13. Weiner HL (1997) Oral tolerance for the treatment of autoimmune diseases. Annu Rev Med 48: 341-351

14. Muir A, Schatz D, Maclaren N (1993) Antigen-specific immunotherapy: oral tolerance and subcutaneous immunization in the treatment of insulin-dependent diabetes. Diabetes Metab Rev 9: 279-287

15. Saï P, Rivereau AS (1996) Prevention of diabetes in the nonobese diabetic mouse by oral immunological treatments: comparative efficiency of human insulin and two bacterial antigens, lipopolyssacharide from Escherichia coli and glycoprotein extract from Klebsiella pneumoniae. Diabete Metab 22: 341-348

16. Saï P, Damgé C, Rivereau AS, Hoeltzel A, Gouin E (1996) Prophylactic oral administration of metabolically active insulin entrapped in isobutylcyanocrylate nanocapsules reduces the incidence of diabetes in NOD mice. J Autoimmun 9: 713-721

17. Zhang ZJ, Davidson L, Eisenbarth G, Weiner HL (1991) Suppression of diabetes in nonobese diabetic mice by oral administration of porcine insulin. Proc Natl Acad Sci USA 88: $10252-10256$

18. Bergerot I, Fabien N, Maguer V, Thivolet C (1994) Oral administration of human insulin to NOD mice generates CD $4+$ T cells that suppress adoptive transfer of diabetes. J Autoimmun 7: 655-663

19. Hancock WW, Sayegh MH, Kwok CA, Weiner HL, Carpenter CB (1993) Oral, but not intravenous, alloantigen prevents accelerated allograft rejection by selective intragraft Th2 cell activation. Transplantation 55: 1112-1118

20. Sayegh MH, Zhang ZJ, Hancock WW, Kwok CA, Carpenter CB, Weiner HL (1992) Down-regulation of the immune response to histocompatibility antigens and prevention of sensitization by skin allografts by orally administered alloantigen. Transplantation 53: 163-166

21. Sayegh MH, Khoury SJ, Hancock WW, Weiner HL, Carpenter CB (1992) Induction of immunity and oral tolerance with polymorphic class II major histocompatibility complex allopeptides in the rat. Proc Natl Acad Sci USA 89: 7762-7766

22. Hrstka J, Hesse UJ, Hrstka V et al. (1992) Prolongation of islet allograft survival following immunologic conditioning by antigen-feeding in the pig. Transplant Proc 24: 663-664

23. Michaels MG, Simmons RL (1994) Xenotransplant-associated zoonoses. Transplantation 57: 1-7

24. Morris PJ (1997) Pig transplants postponed. BMJ 314: 242

25. Martignat L, Saï P, Jestin A (1998) Identification and detection of porcine endogenous retrovirus-like pol sequences and reverse transcriptase activity. Xenotransplantation, 4th International Congress for Xenotransplantation (Abstract) P328

26. Gouin E, Rivereau AS, Duvivier V et al. (1998) Perifusion analysis of insulin secretion from specific pathogen-free large-white pig islets shows satisfactory functional characteristics for xenografts in humans. Diabete Metab 24: 208214

27. Gouin E, Rivereau AS, Darquy S et al. (1997) Minimisation of microbial contamination for potential islet xenografts using specific pathogen-free pigs and a protected environment during tissue preparation. Diabete Metab 23: 537-540

28. Cariolet R (1986) Bilan de 10 années d'utilisation de porcs exempts d'organismes pathogènes spécifiques (E.O.P.S.) à la station de pathologie porcine de Ploufragan. Journées de recherche porcine en France 18: 321-330

29. Ricordi C, Finke EH, Lacy PE (1986) A method for the mass isolation of islets from the adult pig pancreas. Diabetes 35: 649-653

30. Sayegh MH, Khoury SJ, Hancock WW, Weiner HL, Carpenter CB (1996) Mechanisms of oral tolerance by MHC peptides. Ann NY Acad Sci 778: 338-345

31. Satake M, Korsgren O, Ridderstad A, Karlsson-Para A, Wallgren AC, Möller E (1994) Immunological characteristics of islet cell xenotransplantation in humans and rodents. Immunol Rev 141: 191-211

32. Whitacre CC, Gienapp IE, Orosz CG, Bitar DM (1991) Oral tolerance in experimental autoimmune encephalomy- 
elitis III. Evidence for clonal anergy. J Immunol 147: 2155-2163

33. Melamed D, Friedman A (1993) Direct evidence for anergy in $\mathrm{T}$ lymphocytes tolerized by oral administration of ovalbumin. Eur J Immunol 23: 935-942

34. Chen Y, Inobe J, Marks R, Gonnella P, Kuchroo VK, Weiner HL (1995) Peripheral deletion of antigen-reactive T cells in oral tolerance. Nature 376: 177-180

35. Miller SR, Hanson D (1979) Inhibition of specific immune responses by feeding protein antigens. IV. Evidence for tolerance and specific active suppression of cell-mediated immune responses to ovalbumin. J Immunol 123: 2344-2350

36. Miller A, Lider O, Roberts AB, Sporn MB, Weiner HL (1992) Suppressor T cells generated by oral tolerization to myelin basic protein suppress both in vitro and in vivo immune responses by the release of transforming growth factor beta after antigen-specific triggering. Proc Natl Acad Sci USA 89: 421-425

37. Mattingly JA, Waksman BH (1978) Immunologic suppression after oral administration of antigen: I. Specific suppressor cells formed in rat Peyer's patches after oral administration of sheep erythrocytes and their systemic migration. J Immunol 121: 1878-1883

38. Lider O, Santos LBM, Lee CSY, Higgins DJ, Weiner HL (1989) Suppression of experimental autoimmune encephalomyelitis by oral administration of myelin basic protein: II. Suppression of disease and in vitro responses is mediated by CD8 + T lymphocytes. J Immunol 142: 748-752
39. McMenamin C, Holt PG (1993) The natural immune response to inhaled soluble protein antigens involves major histocompatibility complex (MHC) class I-restricted $\mathrm{CD}^{+}{ }^{+}$T cell-mediated but MHC class II-restricted CD4 + $\mathrm{T}$ cell-dependent immune deviation resulting in selective suppression of immunoglobulin E production. J Exp Med 178: 889-899

40. Williams NA, Wilson AD, Bailey M, Bland PW, Stokes CR (1992) Primary antigen-specific T-cell proliferative responses following presentation of soluble protein antigen by cells from the murine small intestine. Immunology 75 : 608-613

41. Halstensen TS, Farstad IN, Scott H, Fausa O, Brandtzaeg P (1990) Intraepithelial TcR $\alpha / \beta+$ lymphocytes express CD45RO more often than the TcR $\gamma / \delta+$ counterparts in coeliac disease. Immunology 71: 460-466

42. Xu AJ, Aicher WK, Taguchi T, Kiyono H, McGhee JR (1992) Selective induction of Th2 cells in murine Peyer's patches by oral immunization. Int Immunol 4: 433-445

43. Fishman LJ, Friedman A, Weiner HL (1994) Different kinetic patterns of cytokine gene expression in vivo in orally tolerant mice. Eur J Immunol 24: 2720-2724

44. Hoyne GF, Thomas WR (1995) T-cell responses to orally administered antigens. Study of the kinetics of lymphokine production after single and multiple feeding. Immunology 84: 304-309 